\title{
Construction of Improved Bacteriophage $\phi 105$ Vectors for Cloning by Transfection in Bacillus subtilis
}

\author{
By D. JONES† AND J. ERRINGTON* \\ Microbiology Unit, Department of Biochemistry, University of Oxford, South Parks Road, \\ Oxford $O X 13 Q U, U K$
}

(Received 13 August 1986; revised 20 October 1986)

A series of improved phage vectors have been constructed, based on Bacillus subtilis bacteriophage $\phi 105$, which can be used to clone genes in $B$. subtilis by direct transfection of protoplasts. The new vectors, designated $\phi 105 \mathrm{~J} 23, \phi 105 \mathrm{~J} 24, \phi 105 \mathrm{~J} 27$ and $\phi 105 \mathrm{~J} 28$, show frequencies of plaque formation that are equal to those of wild-type $\phi 105$. This represents at least a 10 -fold improvement over $\phi 105 \mathrm{~J} 9$, the vector used in previous cloning experiments. Two of the new vectors $\phi 105 \mathrm{~J} 27$ and $\phi 105 \mathrm{~J} 28$ incorporate a mutation, cts-52, that renders the prophage temperature inducible. This has made it possible to devise a rapid small-scale procedure for screening progeny phage for the presence of inserted DNA. The usefulness of the new vectors is illustrated in the accompanying paper by cloning more than $20 \mathrm{~B}$. subtilis sporulation genes.

\section{INTRODUCTION}

A variety of approaches have been used to clone genes in Bacillus subtilis (reviewed by Errington, 1987). Although the use of plasmid vectors has been successful in some instances (Segall \& Losick, 1977; Bonamy \& Szulmajster, 1982) serious limitations have been encountered with many of the standard plasmid vectors. The increase in gene copy number which results when chromosomal genes are cloned into multicopy plasmids may result in deleterious effects on the host cell (Kawamura et al., 1981; Banner et al., 1983). Difficulties have also been encountered when attempting to clone fragments of DNA larger than about $2.5 \mathrm{kbp}$ in certain plasmid vectors (Gryczan \& Dubnau, 1982). Plasmids containing inserts often exhibit structural or segregational instability (see, for example, Bron \& Luxen, 1985), even in recipients which are $\mathrm{Rec}^{-}$(Tanaka, 1979; Uhlen et al., 1981; Hahn \& Dubnau, 1985).

The use of temperate bacteriophages such as $\phi 105$ and $\rho 11$ as cloning vectors provides a means of circumventing many of these difficulties. These phages integrate into the chromosome of $B$. subtilis in a manner analogous to that of phage $\lambda$ in Escherichia coli (Rutberg, 1969) so that genes inserted into the prophage are stably maintained at a copy number of one per chromosome, and this is true even in $\mathrm{Rec}^{+}$strains (Jenkinson \& Mandelstam, 1983; Errington, 1984). Initially, prophage transformation (Kawamura et al., 1979) was used to clone genes in $B$. subtilis bacteriophage vectors. This method relies on the rescue of transformed fragments of phage and chromosomal DNA by recombination with the homologous prophage in the host cell chromosome. Following recombination, the chromosomal DNA may be incorporated into the resident prophage either by replacement or by insertion, which often results in a defective phage (Kawamura et al., 1979). Unfortunately, the vast majority of transformed cells have undergone recombination at the chromosomal locus of the gene rather than insertion of the chromosomal gene into the prophage. Furthermore, relatively large amounts of DNA are required, because lysogenic recipients are about two orders of magnitude less competent in transformation than

† Permanent address: Microbiology Department, University of Cape Town, 22 University Avenue, Rondebosch 7700 , South Africa. 
non-lysogenic strains (Peterson \& Rutberg, 1969; Yasbin et al., 1973; Garro \& Law, 1974) and because extensive processing of the transforming DNA occurs during uptake (Venema, 1979). Nonetheless, prophage transformation has been successfully used to clone a number of biosynthetic and sporulation genes (Kawamura et al., 1979, 1980; Iijima et al., 1980; Ikeuchi et al., 1983; Jenkinson \& Mandelstam, 1983; Savva \& Mandelstam, 1984).

Errington (1984) has described a more efficient cloning method based on direct transfection of $B$. subtilis protoplasts with a new vector, $\phi 105 \mathrm{~J} 9$. This vector was derived from phage $\phi 105 \mathrm{DI}$ : It, which carries a $4 \mathrm{kbp}$ deletion of non-essential DNA (Flock, 1977), by insertion of unique cloning sites for BamHI and $X b a I$. A number of fully functioning sporulation and biosynthetic genes were isolated from $B$. subtilis genomic libraries constructed with the $\phi 105 \mathrm{~J} 9$ vector. However, the construction of comprehensive genomic libraries in $\phi 105 \mathrm{~J} 9$ has proved to be difficult as the number of plaque-forming units obtained with this phage is between 10 and 100 times lower than that obtained with the wild-type phage.

This paper describes the construction of a series of modified phage vectors, also derived from $\phi 105 \mathrm{DI}$ : $1 \mathrm{t}$, in which the cloning sites are inserted at a different position within the phage genome. The new vectors plaque as efficiently as the wild-type. The vector was further developed to incorporate a temperature-inducible lesion, which allows the induction of the lysogenic phage by shifting the growth temperature. An accompanying paper describes the application of one of the new vectors, $\phi 105 \mathrm{~J} 27$, for efficient cloning of $B$. subtilis sporulation genes (Errington \& Jones, 1987).

\section{METHODS}

Bacterial strains, plasmids and phages. These are listed in Table 1. Phages $\phi 105 \mathrm{~J} 78, \phi 105 \mathrm{~J} 83, \phi 105 \mathrm{~J} 86, \phi 105 \mathrm{~J} 92$ and $\phi 105 \mathrm{~J} 95$ are described in the accompanying paper (Errington \& Jones, 1987).

Phage $\phi 105$ preparation and assay. Crude lysates and phage purified by treatment on $\mathrm{CsCl}$ gradients were prepared as described by Jenkinson \& Mandelstam (1983) except that DNAase I treatment was omitted. Lysogenic strains containing temperature-inducible phages were grown at $30^{\circ} \mathrm{C}$ and induced by exposure to heat $\left(10 \mathrm{~min}\right.$ at $48^{\circ} \mathrm{C}$ followed by 1 to $2 \mathrm{~h}$ at $37^{\circ} \mathrm{C}$ ). The quality of extracted DNA from temperature-inducible phages was improved by treatment of the resuspended phage pellet with DNAase I (Sigma, type IV, $25 \mu \mathrm{g} \mathrm{ml}^{-1}$ ) and RNAase (Sigma, type I-A, $25 \mu \mathrm{g} \mathrm{ml}^{-1}$ ) for $15 \mathrm{~min}$ at $22^{\circ} \mathrm{C}$ prior to phage purification on a $\mathrm{CsCl}$ step gradient (Jenkinson \& Mandelstam, 1983). Phages were titrated by standard phage assay methods in tryptose blood agar base (Oxoid) made up at one-third the recommended concentration, overlayed on Oxoid nutrient agar.

Preparation of phage, plasmid and chromosomal DNAs. Phage DNA was prepared from phage purified on $\mathrm{CsCl}$ gradients by extraction with phenol as described previously (Errington, 1984). The plasmid pSGMU1 was prepared from its $E$. coli host on a $\mathrm{CsCl}$ gradient by the alkaline lysis method of Birnboim \& Doly (1979) as described by Maniatis et al. (1982). Supercoiled plasmid DNA was purified by centrifugation to equilibrium in a $\mathrm{CsCl} /$ ethidium bromide density gradient as described by Lovett \& Keggins (1979). Chromosomal DNA from $B$. subtilis 168 was prepared as described previously (Errington, 1984).

Transformation methods. Strains of $B$. subtilis were made competent by the method of Anagnostopoulos \& Spizizen (1961) as modified by Jenkinson (1983). Protoplasts of $B$. subtilis were prepared and transformed with phage DNA by the method of Chang \& Cohen (1979) as modified by Levi-Meyrueis et al. (1980). Protoplast transfections with DNA from phage $\phi 105$ were carried out as described previously (Errington, 1984).

Restriction endonuclease digestion. Restriction endonucleases were obtained from Amersham or BRL and digestion was carried out as recommended by the suppliers.

Ligation conditions. Ligation was carried out in a ligation buffer (Errington, 1984) containing T4 DNA ligase (Boehringer) at a final concentration of 0.02 units $\mu l^{-1}$ for DNA with sticky ends and 0.1 units $\mu l^{-1}$ for blunt ends.

Cloning in E. coli. Transformation of competent $E$. coli strains and use of the plasmid vectors pUCl8 and pSGMU2 are described elsewhere (Fort \& Piggot, 1984; Fort \& Errington, 1985).

Cloning fragments from plasmid pSGMUI into $\phi 105 D I$ : 1 t. Plasmid pSGMU1 DNA $(4 \mu \mathrm{g})$ was digested to completion with EcoRI and $\operatorname{HindIII}\left(6\right.$ units, $2 \mathrm{~h}$ at $37^{\circ} \mathrm{C}$ ). The resulting $5^{\prime}$ protruding single-stranded ends of the restriction fragments were then filled in to give blunt ends in a $20 \mu$ l reaction volume containing all four deoxyribonucleoside triphosphates $\left(15 \mu \mathrm{M}\right.$ each), Tris/ $\mathrm{HCl}(10 \mathrm{mM}, \mathrm{pH} 7 \cdot 5), \mathrm{MgCl}_{2}(10 \mathrm{mM})$ and Klenow polymerase (Amersham, 8 units). After $10 \mathrm{~min}$ at $22^{\circ} \mathrm{C}$ the reaction was terminated by phenol extraction and ethanol precipitation. Phage $\phi 105 \mathrm{DI}$ : 1t DNA $(3 \mu \mathrm{g})$ was digested to completion with $\operatorname{SmaI}\left(8 \mathrm{units}, 2 \mathrm{~h}\right.$ at $37^{\circ} \mathrm{C}$ ). Following removal of the restriction endonucleases, a $20 \mu \mathrm{l}$ ligation mixture was prepared containing $30 \mu \mathrm{g}$ pSGMU1 and $10 \mu \mathrm{g} \phi 105 \mathrm{DI}$ : It digested as indicated above. The reaction mixture was incubated for $18 \mathrm{~h} \mathrm{at} 15^{\circ} \mathrm{C}$ and $2 \mu \mathrm{l}$ and $5 \mu \mathrm{l}$ samples were used to transform competent cells of $B$. subtilis strain CU267( $\phi 105 \mathrm{DI}: 1 \mathrm{t})$. After $30 \mathrm{~min}$ at $37^{\circ} \mathrm{C}$ the cells were plated on nutrient agar containing chloramphenicol $\left(5 \mu \mathrm{g} \mathrm{ml}^{-1}\right)$. 
Table 1. Bacterial strains, bacteriophages and plasmids

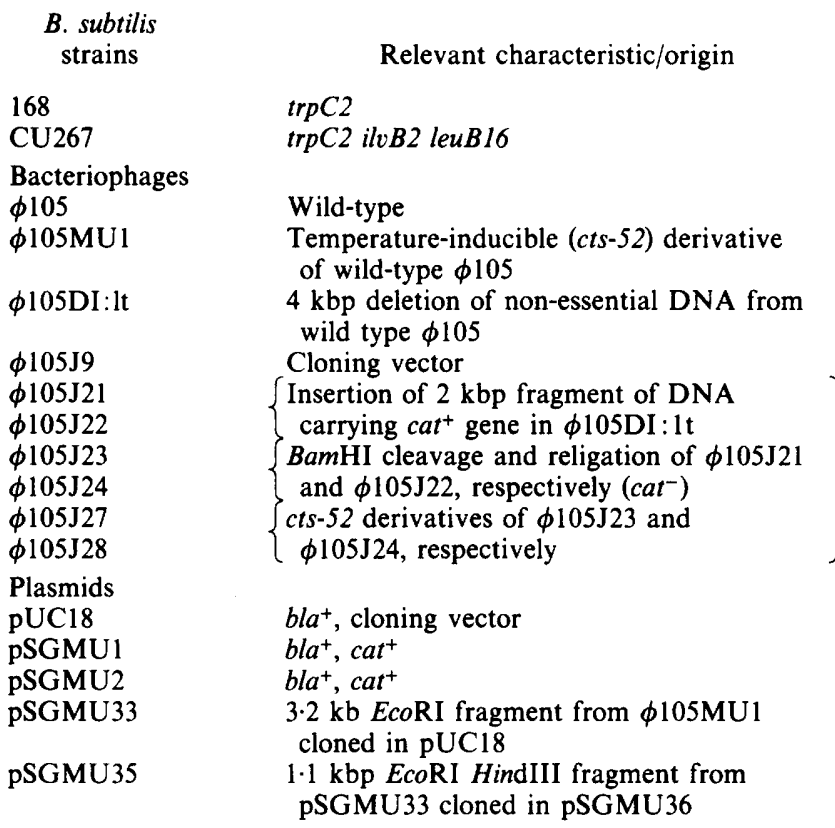

\author{
Reference/origin \\ Laboratory stock \\ S. A. Zahler* \\ Rutberg (1969) \\ H. F. Jenkinson \& D. J. Tipper† \\ (unpublished results) \\ Flock (1977)
}

Errington (1984)

This paper

\author{
Norrander et al. (1983) \\ Errington (1984) \\ Fort \& Errington (1985)
}

This paper

This paper

* S. A. Zahler, Genetics \& Development Department, Cornell University, Ithaca, NY, USA.

$\dagger$ H. F. Jenkinson, Department of Oral Biology, University of Otago, Dunedin, New Zealand. D. J. Tipper, Department of Molecular Genetics \& Microbiology, University of Massachusetts Medical School, Worcester, Massachusetts 01605, USA.

Derivation of phages $\phi 105 \mathrm{~J} 23$ and $\phi 105 \mathrm{~J} 24$. DNA extracted from $\phi 105 \mathrm{~J} 21$ or $\phi 105 \mathrm{~J} 22(1 \mu \mathrm{g})$ was digested to completion with BamHI, religated in a $50 \mu 1$ reaction volume $\left(18 \mathrm{~h}\right.$ at $\left.15^{\circ} \mathrm{C}\right)$ and used to transfect protoplasts of strain CU267 (non-lysogenic). Lysogenic cells from the centres of the resulting plaques were tested for loss of chloramphenicol resistance by streaking on nutrient agar (Oxoid) containing chloramphenicol $\left(5 \mu \mathrm{g} \mathrm{ml}^{-1}\right)$.

Rapid small-scale procedure for isolating phage DNA. Small-scale phage lysates $(5 \mathrm{ml})$ were prepared by temperature induction of lysogens as described above except that $30 \mathrm{~min}$ after the shift in temperature, DNAase ( $1 \mu \mathrm{l}$ of a stock solution, $1 \mathrm{mg} \mathrm{ml}^{-1}$, stored in $150 \mathrm{mM}-\mathrm{NaCl}, 10 \%(\mathrm{v} / \mathrm{v})$ glycerol at $-20^{\circ} \mathrm{C}$ ) and RNAase $(5 \mu \mathrm{l}$ of a stock solution, $10 \mathrm{mg} \mathrm{ml}^{-1}$, stored in $50 \mathrm{mM}-\mathrm{Tris} / \mathrm{HCl}, 5 \mathrm{mM}-\mathrm{EDTA}, 100 \mathrm{mM}-\mathrm{NaCl}$ at $-20^{\circ} \mathrm{C}$ ) were added to digest nucleic acids released from the host upon lysis. A $1 \mathrm{ml}$ sample of lysate was centrifuged (Beckman microfuge, $5 \mathrm{~min}$ ) to remove cell debris and unlysed cells and to the clear supernatant was added $500 \mu \mathrm{l}$ of a solution containing polyethylene glycol $(30 \%, \mathrm{w} / \mathrm{v})$ and $\mathrm{NaCl}(1.2 \mathrm{M})$. After at least $1 \mathrm{~h}$ on ice, the precipitated phage was recovered by centrifugation (Beckman microfuge, $2 \mathrm{~min}$ ) taking care to remove as much of the supernatant as possible. The phage pellet was resuspended in $50 \mu \mathrm{l}$ of a solution containing: Tris/ $\mathrm{HCl}(10 \mathrm{mM}$, pH 7.5); cyclohexanediaminetetraacetic acid (CDTA, $5 \mathrm{mM}) ; 2$-mercaptoethanol (15 mM) and sodium dodecyl sulphate $(0.25 \% \mathrm{w} / \mathrm{v})$. The mixture was vortex mixed briefly, heated at $70{ }^{\circ} \mathrm{C}$ for $10 \mathrm{~min}$ then cooled to $22^{\circ} \mathrm{C}$. Potassium acetate $(12.5 \mu \mathrm{l}$ of a $5 \mathrm{M}$ solution) was added and the tube was placed on ice for $30 \mathrm{~min}$. Insoluble material was removed by centrifugation (Beckman microfuge, $5 \mathrm{~min}$ ) and the phage DNA in the supernatant was precipitated by adding 2 vols ethanol. The precipitate was recovered by centrifugation (as above) and redissolved in $50 \mu \mathrm{TC}$ buffer $(10 \mathrm{~mm}$-Tris/ $\mathrm{HCl}, \mathrm{pH} 7.5 ; 1 \mathrm{~mm}-\mathrm{CDTA})$ containing 2-mercaptoethanol $(15 \mathrm{~mm})$. The DNA was extracted with 1 vol. phenol, then reprecipitated with ethanol in the presence of $0.3 \mathrm{M}$-sodium acetate. The precipitate was recovered by centrifugation, washed with $80 \%(\mathrm{v} / \mathrm{v})$ ethanol then dried in vacuo and redissolved in $10 \mu \mathrm{l} \mathrm{TC}$ buffer. This procedure routinely yielded about $2 \mu \mathrm{g}$ of phage DNA, enough for two or three restriction digestions.

RESULTS AND DISCUSSION

Construction of modified $\phi 105$ cloning vectors

Although the bacteriophage cloning vector $\phi 105 \mathrm{~J} 9$ has been used successfully to clone a number of sporulation genes (Errington, 1984; Lopez-Diaz et al., 1986; James \& Mandelstam, 

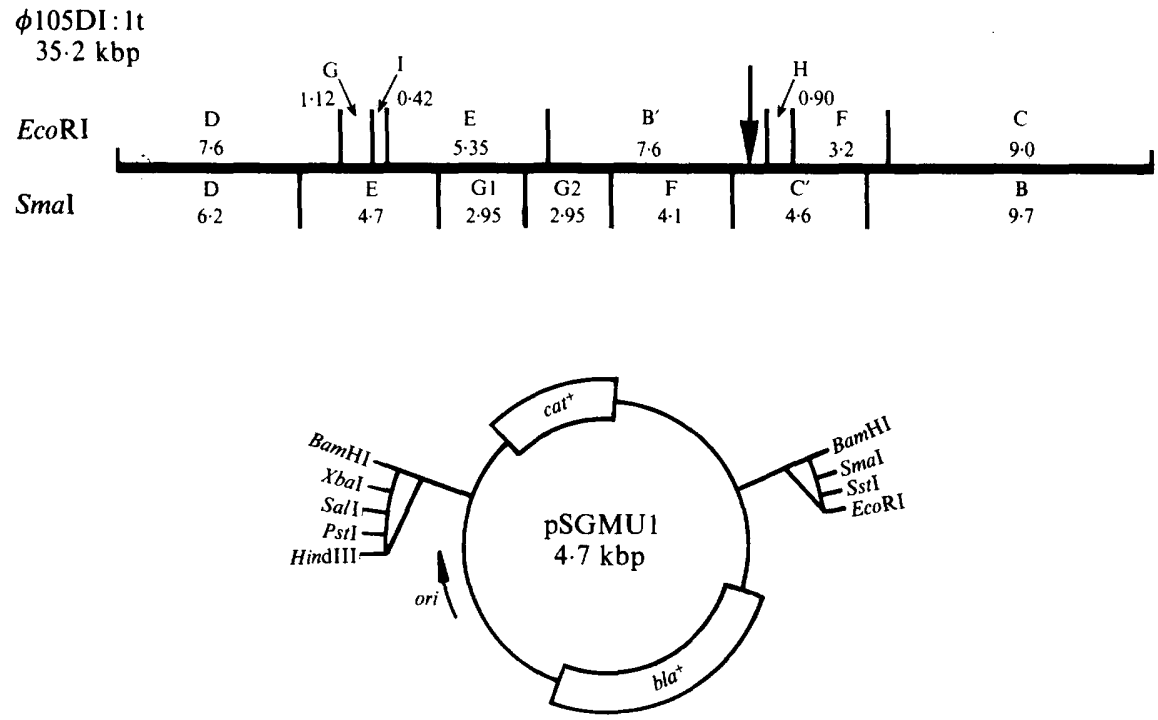

Fig. 1. Restriction maps of phage $\phi 105 \mathrm{DI}: 1 \mathrm{t}$ and plasmid pSGMU1. EcoRI and SmaI restriction sites and the one-letter designations and sizes $(\mathrm{kbp})$ of the resultant fragments are shown for the phage (Bugaichuk et al., 1984). The thick arrow indicates the location of a $4 \mathrm{kbp}$ deletion of non-essential DNA in this phage (Flock, 1977).

Plasmid pSGMU1 (Errington, 1984), shown on an expanded scale, contains a chloramphenicolresistance determinant, $\mathrm{Cat}^{+}$, as a $2.0 \mathrm{kbp} \mathrm{BamHI}$ fragment of DNA inserted into the polylinker region of plasmid pUC13. The origin of replication (ori) and ampicillin-resistance gene (bla $\left.{ }^{+}\right)$of the vector are also shown.

1985; Turner \& Mandelstam, 1986; A. J. Smith \& J. Mandelstam, unpublished results) it suffers from the disadvantage that the number of plaque-forming units produced after induction of the phage is significantly lower than that produced by the wild-type phage. In an effort to obtain a modified vector able to plaque at the same frequency as the wild-type phage, a procedure similar to that used to construct the vector $\phi 105 \mathrm{~J} 9$ (Errington, 1984) was used to insert a cloning site into an alternative position within the genome of $\phi 105 \mathrm{DI}$ : 1t (Fig. 1). Plasmid pSGMU1 was digested with HindIII and EcoRI to produce two fragments (see Fig. 1). One of these fragments contained the $\mathrm{Cat}^{+}$gene, flanking BamHI sites and polylinker regions on a molecule of $2 \mathrm{kbp}$ with one HindIII and one EcoRI cohesive end. The cohesive ends were filled in to produce blunt ends and the fragments were then blunt-end ligated to fragments of $\phi 105 \mathrm{DI}$ : 1t digested with Smal, which restricts $\phi 105 \mathrm{DI}$ : 1t DNA at six sites (Bugaichuk et al., 1984). Transformation of strain CU267( $\phi 105 \mathrm{DI}: 1 \mathrm{t})$ enabled the fragment containing the $\mathrm{cat}^{+}$gene flanked by the appropriate phage fragments to be rescued onto the resident prophage genome by crossing over. The first transformation experiment produced 150 colonies; these were divided into 15 pools, each containing 10 colonies, which, after induction of the phage, were screened for plaque formation and the ability to transduce chloramphenicol resistance. Lysates produced from pooled chloramphenicol-resistant colonies were filtered and diluted $10^{6}$-fold. Ten of the pooled lysates produced plaques at a dilution of $10^{-6}$ and eight of these pools produced phages that transduced sensitive host strains to chloramphenicol resistance at the same dilution. Fifty plaques from each successful pool were tested and all contained chloramphenicol-resistant lysogenic cells.

DNA was prepared from phages isolated from the eight different pools and restriction maps were constructed following digestion with EcoRI or SmaI (Fig. 2). The EcoRI digestions of all eight phages showed that one of the co-migrating fragments of $7.6 \mathrm{kbp}$ (fragments $\mathrm{D}$ and $\mathrm{B}^{\prime}$; Fig. 1) had been replaced by a larger fragment of about $9.6 \mathrm{kbp}$. None of the other EcoRI fragments was affected. 


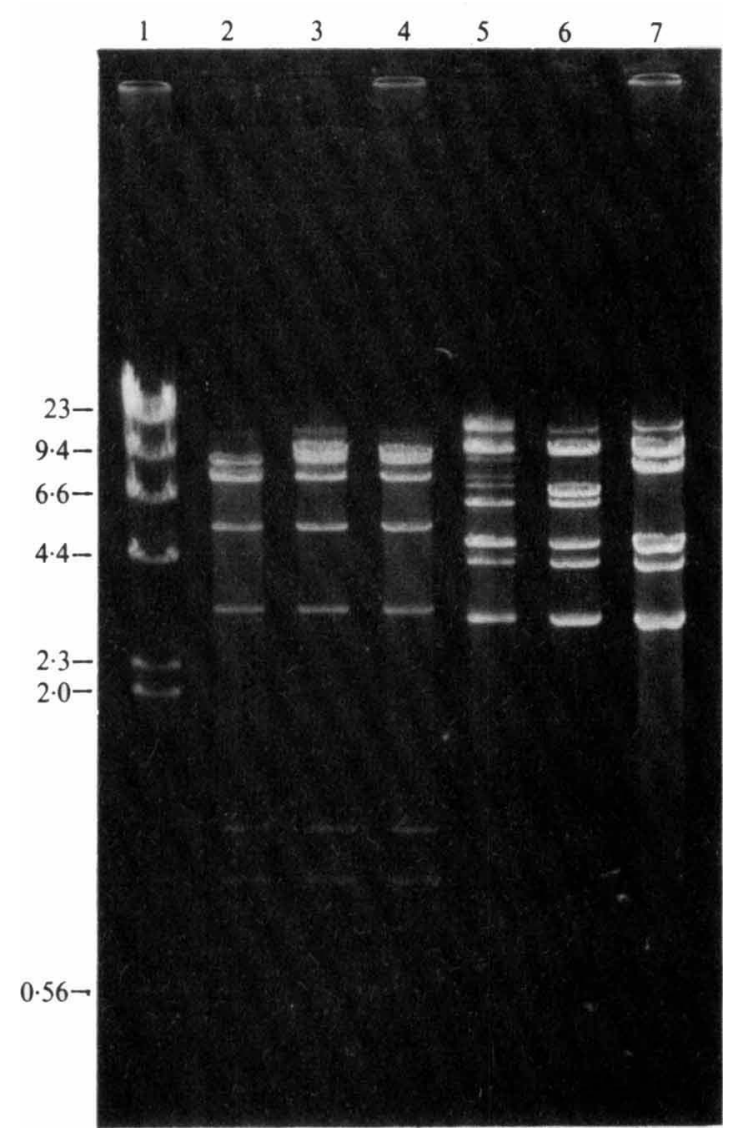

Fig. 2. Agarose gel electrophoresis $(0 \cdot 7 \%, \mathrm{w} / \mathrm{v})$ of DNA from phages $\phi 105 \mathrm{DI}: 1 \mathrm{t}$ (tracks 2 and 5 ), $\phi 105 \mathrm{~J} 21$ (tracks 3 and 6) and $\phi 105 \mathrm{~J} 22$ (tracks 4 and 7) digested with EcoRI (tracks 2 to 4) or SmaI (tracks 5 to 7). Lane 1 contains $M_{\mathrm{r}}$ markers (phage $\lambda$ DNA digested with HindIII) with their sizes (kbp) indicated at the left.

Two types of pattern were observed in the SmaI digestions. One type of phage (designated $\phi 105 \mathrm{~J} 21$ ) appeared to have lost one of the co-migrating fragments of about $4.6 \mathrm{kbp}$ (fragments $\mathrm{E}$ and $C^{\prime}$ ), and a new fragment of about $6.6 \mathrm{kbp}$ was present. There were two possible locations for the $\mathrm{cat}^{+}$-encoding insertion in this phage type: either between SmaI fragments D and E or between fragments $\mathrm{F}$ and $\mathrm{C}^{\prime}$. HindIII digestions demonstrated that the former alternative was correct (data not shown). The other type of phage (designated $\phi 105 \mathrm{~J} 22$ ) had lost the $6.2 \mathrm{kbp}$ fragment (D) and a new fragment of about $8.2 \mathrm{kbp}$ was present. The only possible location for this insertion was also between SmaI fragments D and E. The differences between the restriction patterns of the two phage types are due to the orientation of the $2.0 \mathrm{kbp}$ insertion, which has an asymmetric SmaI site.

The $2.0 \mathrm{kbp}$ BamHI fragment of DNA carrying the cat gene was removed from phages $\phi 105 \mathrm{~J} 21$ and $\phi 105 \mathrm{~J} 22$ by cleavage with BamHI followed by religation and transfection of protoplasts of strain CU267 (non-lysogenic). This procedure, like that described for the construction of $\phi 105 \mathrm{~J} 9$ (Errington, 1984), leaves behind in the prophage the polylinker restriction sites that flanked the $\mathrm{cat}^{+}$gene insert. Of the 60 plaques tested from each ligation about $20 \%$ contained chloramphenicol-resistant lysogenic bacteria. The remainder of the phages were presumably generated by re-circularization of the phage DNA without the insert containing the cat gene. 


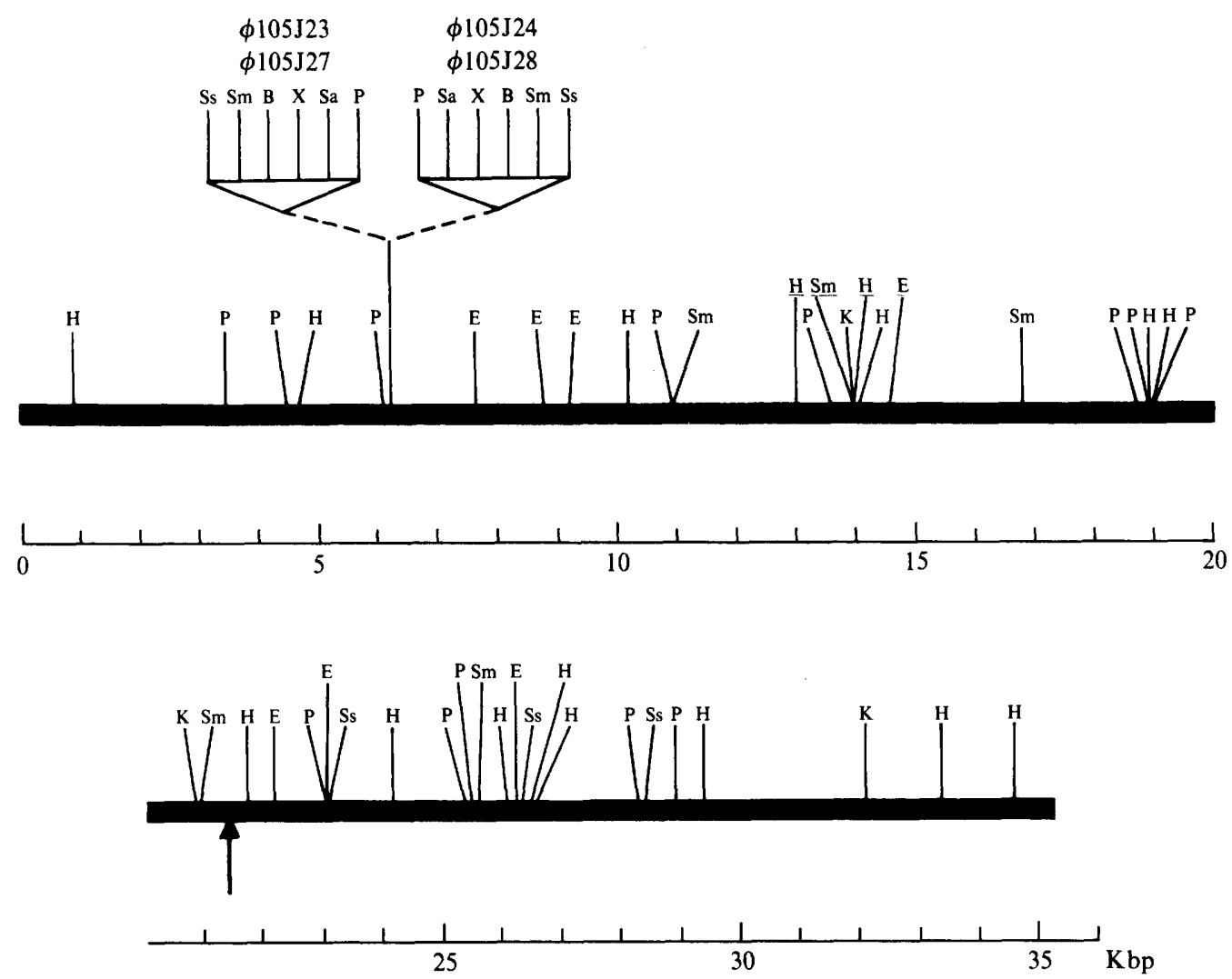

Fig. 3. Detailed restriction map of the new phage vectors $\phi 105 \mathrm{~J} 23$ and $\phi 105 \mathrm{~J} 24$. Some minor adjustments to the map described by Bugaichuk et al. (1984) have been made in view of more recent data (results not shown). The arrow indicates the approximate location of a $4 \mathrm{kbp}$ deletion of nonessential DNA in these phages, which are derived from phage $\phi 105 \mathrm{DI}$ : 1t (Flock, 1977). The order of restriction sites in the polylinker regions inserted into phage $\phi 105 \mathrm{~J} 23$ and $\phi 105 \mathrm{~J} 24$ is shown on an expanded scale, BamHI (B), EcoRI (E), HindIII (H), KpnI (K), PstI (P), SalI (Sa), SmaI (Sm), SstI (Ss), $X b a \mathrm{I}(\mathrm{X})$. Phages $\phi 105 \mathrm{~J} 27$ and $\phi 105 \mathrm{~J} 28$ have the same restriction patterns as those of $\phi 105 \mathrm{~J} 23$ and $\phi 105 \mathrm{~J} 24$, respectively.

DNA was then prepared from the two chloramphenicol-sensitive phage types. Single and double digestions with BamHI and HindIII confirmed the structures of the new phages $\phi 105 \mathrm{~J} 23$ and $\phi 105 \mathrm{~J} 24$ (not shown). Both of these phages had lost the $2 \mathrm{kbp}$ insert and had a single BamHI site. The unique BamHI and $X b a \mathrm{I}$ sites, and the second SalI site, available for cloning in $\phi 105 \mathrm{~J} 23$ and $\phi 105 \mathrm{~J} 24$, are similar to those present in the $\phi 105 \mathrm{~J} 9$ vector constructed previously (Errington, 1984). However the frequencies of plaque formation by the phages $\phi 105 \mathrm{~J} 21, \mathrm{~J} 22, \mathrm{~J} 23$ and $\mathrm{J} 24$ were significantly higher than those obtained with $\phi 105 \mathrm{~J} 9$. In three independent assays, the new $\phi 105$ vectors were observed to plaque at frequencies similar to those obtained with the $\phi 105$ wild-type and $\phi 105 \mathrm{DI}$ : 1 t phages $\left(1\right.$ to $5 \times 10^{9}$ p.f.u. $\left.\mathrm{ml}^{-1}\right)$. This was between 10- and 100-fold higher than the frequency obtained with $\phi 105 \mathrm{~J} 9$ (between $5 \times 10^{7}$ and $2 \times 10^{8}$ p.f.u. $\mathrm{ml}^{-1}$, data not shown). A similar improvement over $\phi 105 \mathrm{~J} 9$ was observed in the frequencies of transfection of protoplasts in terms of progeny phage per $\mu \mathrm{g}$ transfecting DNA. Use of these new vectors should therefore enhance the efficiency of the cloning system by about an order of magnitude.

Detailed restriction maps of the new vectors are shown in Fig. 3. The new vectors also include two extra restriction sites, $S s t \mathrm{I}$ and $S m a \mathrm{I}$, that were not incorporated into $\phi 105 \mathrm{~J} 9$. Although $\phi 105$ has additional sites for these enzymes, their inclusion facilitates the complete removal of 


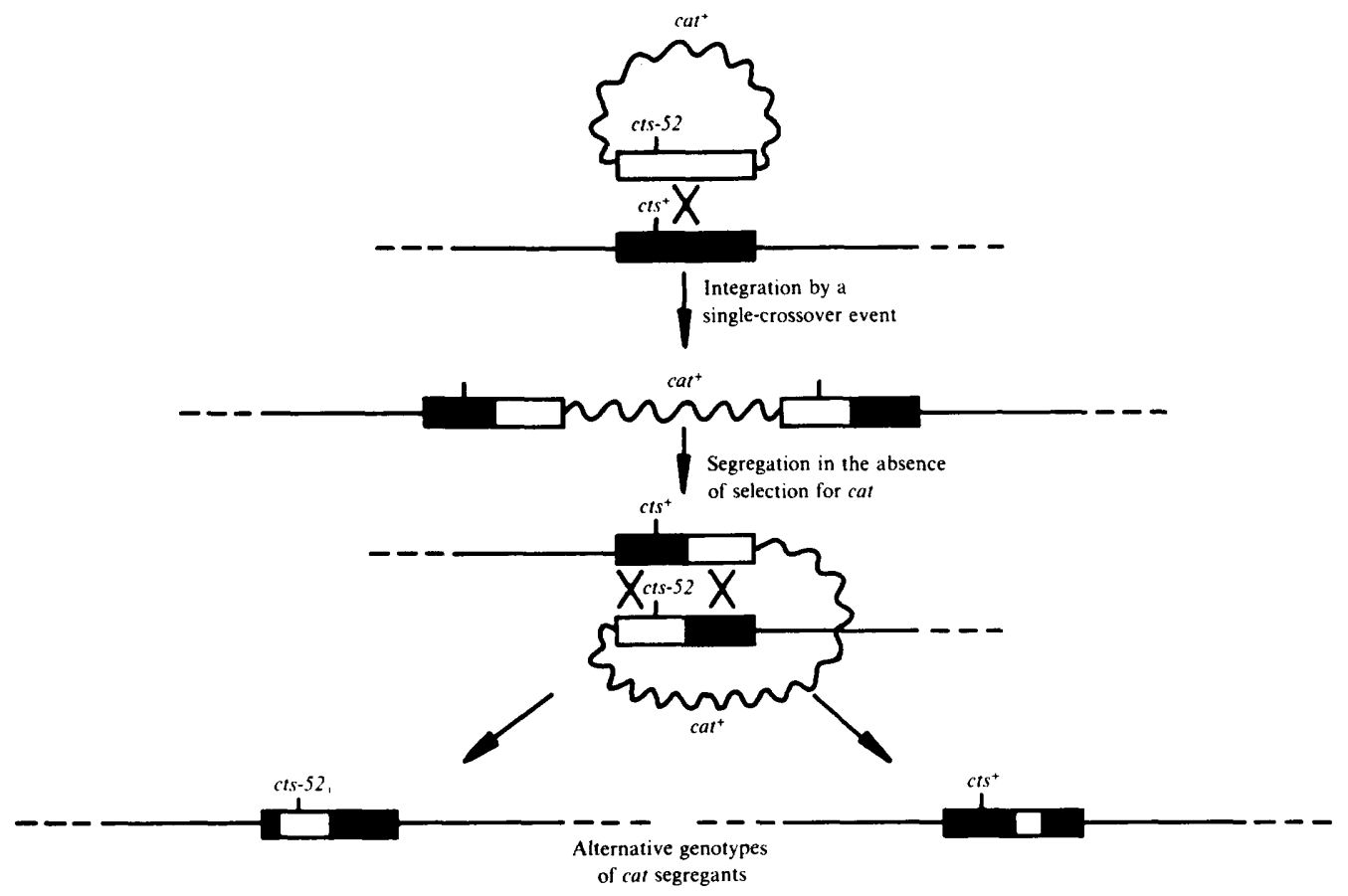

Fig. 4. Transfer of the $c t s-52$ allele onto the $\phi 105$ prophage by integration and excision of plasmid pSGMU35. This plasmid contains a $1.1 \mathrm{kbp} H$ indIII-EcoRI fragment of DNA from $\phi 105 c t s-52$ that includes the $c t s-52$ mutation. It also carries a chloramphenicol-resistance determinant, $c a t^{+}$, and it can replicate autonomously in $E$. coli but not in $B$. subtilis (Fort \& Errington, 1985). In a recipient strain lysogenic for phage $\phi 105$, chloramphenicol-resistant transformants can arise by integration of the plasmid via a single-crossover event (Duncan et al., 1978; Haldenwang et al., 1980) involving the cloned sequence in plasmid pSGMU35 (open box) and its homologue on the $\phi 105$ prophage (filled box). After removal of the selective pressure, excision of the inserted plasmid can occur by a reversal of the integration mechanism. The resultant prophage may carry either the $c t s-52$ allele or its wild-type homologue, depending upon the location of the single crossover (Gutterson \& Koshland, 1983).

cloned DNAs from flanking $\phi 105$ sequences, for subsequent subcloning or restriction analysis. The location of this cloning site at a $S m a I$ site $6.2 \mathrm{kbp}$ from the left end of the phage defines a previously unknown region of the phage genome that is apparently non-essential for lytic growth or lysogeny.

\section{Temperature inducible derivatives of the new vectors}

Armentrout \& Rutberg (1971) have described $\phi 105$ mutants that are temperature inducible (cts). Lysogens carrying cts prophages grow normally at $30^{\circ} \mathrm{C}$ but at temperatures above $42{ }^{\circ} \mathrm{C}$ lytic phage growth is induced. The location of the cts mutations, which presumably identify a phage repressor gene, has been mapped to a $1.1 \mathrm{kbp}$ HindIII-EcoRI fragment of $\phi 105$ (Dhaese et al., 1984). Incorporation of the $c t s-52$ allele into the new vectors would facilitate the preparation of phage DNA and the screening of recombinants. Temperature induction of phage has several advantages over induction by mitomycin $C$. The latter is highly toxic and it also induces the cryptic prophage PBSX (Okamoto et al., 1968), which must be separated from $\phi 105$ phage particles by centrifugation on a $\mathrm{CsCl}$ density gradient (Jenkinson \& Mandelstam, 1983). Progeny obtained following transfection with cts vectors can be screened for the presence of inserts by a convenient small-scale procedure (see below and in Methods).

A marker replacement technique, similar to that described by Gutterson \& Koshland (1983), was used to transfer the $c t s-52$ allele to various phage vectors. The $3.2 \mathrm{kbp} E c o$ RI fragment, F, from $\phi 105 \mathrm{MU} 1$ was cloned into the unique EcoRI site of plasmid pUC! 8 to yield pSGMU33, 


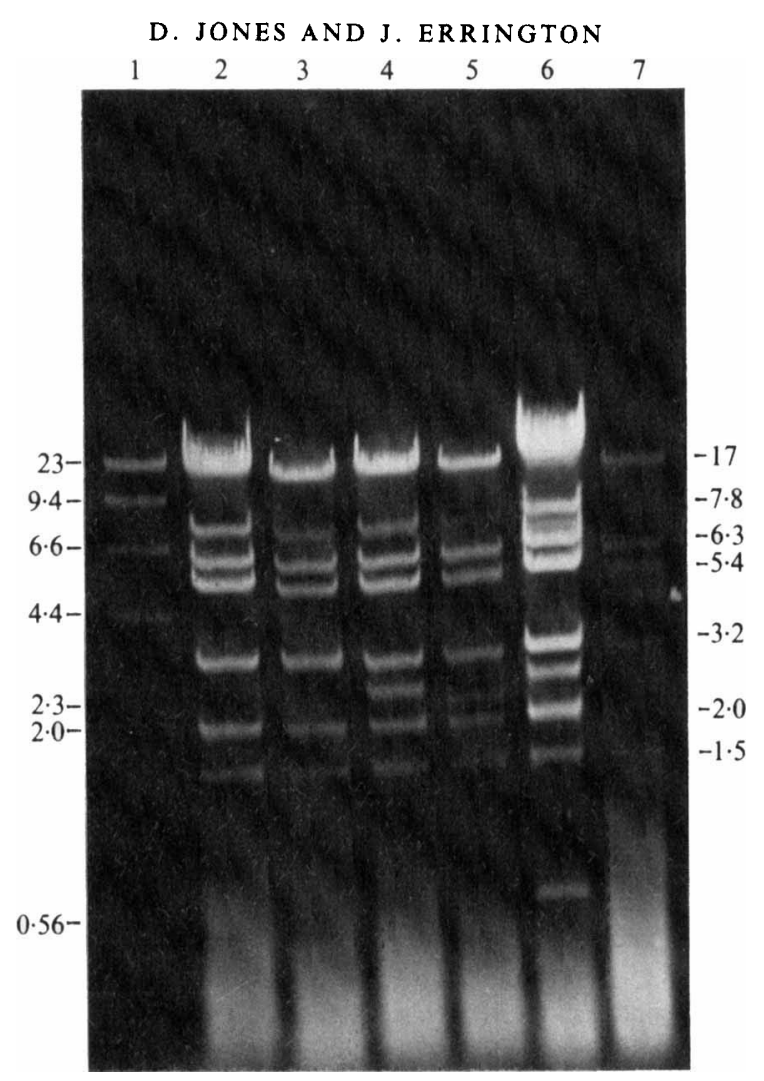

Fig. 5. Agarose gel electrophoresis $(0.6 \%, \mathrm{w} / \mathrm{v})$ of $S s t \mathrm{I}, \mathrm{Sall}$ double restriction digestions of phage DNA 'mini-preps'. DNA was prepared from $1 \mathrm{ml}$ samples of crude phage lysates as described in Methods, and doubly-digested with $S a I I$ and $S s t I$. To the left are indicated the molecular sizes (kbp) of the marker fragments produced by digestion of phage $\lambda$ DNA with HindIII (track 1). To the right are the sizes of the fragments of DNA common to the $\phi 105$ derivatives. The $7.8 \mathrm{kbp}$ fragment that is present in some lanes is the result of annealing of the 6.3 and $1.5 \mathrm{kbp}$ fragments via the phage cohesive ends. The smear at the bottom of the picture represents contaminating fragments of host chromosomal DNA and some RNA. The following phages are shown: $\phi 105 \mathrm{~J} 27$ (lane 2), $\phi 105 \mathrm{~J} 78$ (3), $\phi 105 \mathrm{~J} 83$ (4), $\phi 105 \mathrm{~J} 86$ (5), $\phi 105 \mathrm{~J} 92$ (6), $\phi 105 \mathrm{~J} 95$ (7).

which was isolated as a plasmid containing an insert of the correct size and EcoRI, HindIII restriction pattern. The $1.1 \mathrm{kbp}$ EcoRI-HindIII fragment from plasmid pSGMU33 was then subcloned into the integration plasmid pSGMU2 (Fort \& Errington, 1985) between its unique $H$ indIII and EcoRI sites to yield plasmid pSGMU35. Although plasmid pSGMU2 cannot replicate autonomously in $B$. subtilis it can be transformed successfully into $B$. subtilis strains following selection for chloramphenicol resistance if a fragment of DNA has been inserted into it that has homology to the $B$. subtilis chromosome. This has been shown to result from integration of the plasmid by a single-crossover event that leads to duplication of the cloned region of homology on each side of the inserted plasmid as shown in Fig. 4 (Duncan et al., 1978; Haldenwang et al., 1980). Derivatives of strain CU267 lysogenic for phages $\phi 105 \mathrm{~J} 23$ and $\phi 105 \mathrm{~J} 24$ were transformed with plasmid pSGMU35 DNA and plated at $30^{\circ} \mathrm{C}$ with selection for chloramphenicol resistance. In both cases about $10^{3}$ transformants were obtained. Fifty independent colonies from each cross were all temperature-insensitive, suggesting that integration of the plasmid does not disrupt expression of the phage repressor gene (see Piggot $e t$ al., 1984, for example, for a full account of the use of integrational plasmids to analyse transcription units). A single chloramphenicol-resistant colony from each transformation was grown in BHIB under non-selective conditions for about 30 generations to allow segregation of chloramphenicol-sensitive individuals by a reversal of the integration mechanism. It was 
expected that a proportion of the chloramphenicol-sensitive segregants would retain the $c t s-52$ allele, depending upon which side of the marker the single-crossover event had occurred. The cultures were therefore heat-induced and the filter-sterilized supernatant was tested for the production of clear plaques on strain CU 267 grown at $42^{\circ} \mathrm{C}$. In both cases about $10^{4}$ clear p.f.u. $\mathrm{ml}^{-1}$ were obtained. Phage from single clear plaques were isolated and replated at $30^{\circ} \mathrm{C}$ to enable lysogens to be obtained, and these were chloramphenicol sensitive as expected. The temperature-inducible derivatives of $\phi 105 \mathrm{~J} 23$ and $\phi 105 \mathrm{~J} 24$ were designated $\phi 105 \mathrm{~J} 27$ and $\phi 105 \mathrm{~J} 28$ respectively. Both derivatives were indistinguishable from their respective parents in terms of restriction enzyme analysis.

\section{Rapid small-scale procedure for screening progeny phage}

Incorporation of the cts-52 allele into the cloning vectors has made it possible to devise a rapid, small-scale procedure to determine whether progeny phage contain inserts (see Methods). To illustrate the results that may be obtained with the new procedure, it was applied to strains containing the vector prophage $\phi 105 \mathrm{~J} 27$ and to some of the derivatives described in the accompanying paper (Errington \& Jones, 1987). Fig. 5 shows an agarose gel of these small-scale DNA preparations that had been doubly digested with $S s t I$ and $S a l I$. These enzymes cleave on the left and right sides of the Bam HI cloning site in $\phi 105 \mathrm{~J} 27$ respectively (Fig. 3). These enzymes therefore release the cloned insert and they also generate vector fragments of approximately 17 , $6.3,5.4,3.2,2.0$ and $1.5 \mathrm{kbp}$, which provide useful internal $M_{\mathrm{r}}$ markers. (The fragment of $7.8 \mathrm{kbp}$ results from annealing of the 6.3 and $1.5 \mathrm{kbp}$ fragments via the phage cohesive ends.) Clearly a comparison of the track containing vector DNA with the others indicates that the new derivatives all contain DNA inserts. This procedure should be particularly useful where no direct selection for the presence of an insert is possible.

The general advantages of cloning in $B$. subtilis with the $\phi 105$ transfection system have been discussed fully (Errington, 1984). The improved effectiveness of the new vectors is illustrated by the results presented in the accompanying paper (Errington \& Jones, 1987), which describes the use of one of the new vectors, $\phi 105 \mathrm{~J} 27$, to construct genomic libraries from which DNA from more than 20 different $B$. subtilis sporulation loci have been isolated.

We thank Ms Gillian Roberts and Mrs Wyn Jones for excellent technical assistance and Dr P. Butler for suggesting improvements to the 'mini prep' procedure. We are grateful for the continual advice and encouragement provided by Professor J. Mandelstam. This work was supported in part by the Science and Engineering Research Council. J.E. is the recipient of a Royal Society 1983 Research Fellowship.

\section{REFERENCES}

Anagnostopoulos, C. \& SpIzizen, J. (1961). Requirements for transformation in Bacillus subtilis. Journal of Bacteriology 81, 741-746.

Armentrout, R. W. \& Rutberg, L. (1971). Heat induction of prophage $\phi 105$ in Bacillus subtilis: replication of the bacterial and bacteriophage genomes. Journal of Virology 8, 455-468.

Banner, C. D. B., Moran, C. P., JR \& Losick, R. (1983). Deletion analysis of a complex promoter for a developmentally regulated gene from Bacillus subtilis. Journal of Molecular Biology 168, 351-365.

Birnboim, H. C. \& DOLY, J. (1979). A rapid alkaline extraction procedure for screening recombinant plasmid DNA. Nucleic Acids Research 7, 1513-1523.

Bonamy, C. \& Szulmajster, J. (1982). Cloning and expression of Bacillus subtilis sporulation genes. Molecular and General Genetics 188, 202-210.

BRON, S. \& LUXEN, E. (1985). Segregational instability of pUB110-derived recombinant plasmids in Bacillus subtilis. Plasmid 14, 235-244.
Bugaichuk, U. D., Deadman, M., Errington, J. \& Savva, D. (1984). Restriction enzyme analysis of Bacillus subtilis bacteriophage $\phi 105$ DNA. Journal of General Microbiology 130, 2165-2167.

Chang, S. \& Cohen, S. N. (1979). High frequency transformation of Bacillus subtilis protoplasts by plasmid DNA. Molecular and General Genetics 168, $111-115$.

Dhaese, P., Hussey, C. \& Van Montagu, M. (1984). Thermo-inducible gene expression in Bacillus subtilis using transcriptional regulatory elements from temperate phage $\phi 105$. Gene 32, 181-194.

DunCAN, C. H., Wilson, G. A. \& Young. F. E. (1978). Mechanism of integrating foreign DNA during transformation of Bacillus subtilis. Proceedings of the National Academy of Sciences of the United States of America 75, 3664-3668.

ERrINGTON, J. (1984). Efficient Bacillus subtilis cloning system using bacteriophage vector $\phi 105 \mathrm{~J} 9$. Journal of General Microbiology 130, 2615-2628. 
ERRINGton, J. (1987). Generalized cloning vectors for Bacillus subtilis. In Vectors: a Survey of Molecular Cloning Vectors and Their Uses. Edited by $\mathrm{D}$. Denhardt \& R. Rodriguez. Boston: Butterworths (in the Press).

ERrington, J. \& Jones, D. (1987). Cloning in Bacillus subtilis by transfection with bacteriophage vector $\phi 105 \mathrm{~J} 27$ : isolation and preliminary characterization of transducing phages for 23 sporulation loci. Journal of General Microbiology 133, 493-502.

FLOCK, J.-I. (1977). Deletion mutants of temperate Bacillus subtilis bacteriophage $\phi 105$. Molecular and General Genetics 155, 241-247.

ForT, P. \& ERrington, J. (1985). Nucleotide sequence and complementation analysis of a polycistronic sporulation operon, spoVA, in Bacillus subtilis. Journal of General Microbiology 131, 1091-1105.

ForT, P. \& PigGot, P. J. (1984). Nucleotide sequence of sporulation locus spoIIA in Bacillus subtilis. Journal of General Microbiology 130, 2147-2153.

Garro, A. J. \& LAW, M.-F. (1974). Relationship between lysogeny, spontaneous induction, and transformation efficiencies in Bacillus subtilis. Journal of Bacteriology 120, 1256-1259.

GryCZAN, T. \& DUBNAU, D. (1982). Direct selection of recombinant plasmids in Bacillus subtilis. Gene 20 , 459-469.

Gutterson, N. I. \& Koshland, D. E., JR (1983). Replacement and amplification of bacterial genes with sequences altered in vitro. Proceedings of the National Academy of Sciences of the United States of America 80, 4894-4898.

HahN, J. \& DubnaU, D. (1985). Analysis of plasmid deletional instability in Bacillus subtilis. Journal of Bacteriology 162, 1014-1023.

Haldenwang, W. G., Banner, C. D., Ollington, J. F., Losick, R., Hoch, J. A., O'ConNoR, M. B. \& Sonenshein, A. L. (1980). Mapping a cloned gene under sporulation control by insertion of a drug resistance marker. Journal of Bacteriology 142, 90-98.

Iijima, T., Kawamura, F., Saito, H. \& Ikeda, Y. (1980). A specialized transducing phage constructed from Bacillus subtilis phage $\phi 105$. Gene 9, 115-126.

IKEUCHI, T., KUDOH, J. \& KuRAHASHI, K. (1983). Cloning of sporulation genes $\operatorname{spo} 0 A$ and $s p o 0 C$ of Bacillus subtilis onto $\rho 11$ temperate bacteriophage. Journal of Bacteriology 154, 988-991.

James, W. \& Mandelstam, J. (1985). Protease production during sporulation of germination mutants of Bacillus subtilis and the cloning of a functional gerE gene. Journal of General Microbiology 131, 2421-2430.

JENKINSON, H. F. (1983). Altered arrangement of proteins in the spore coat of a germination mutant of Bacillus subtilis. Journal of General Microbiology 129, 1945-1958.

Jenkinson, H. F. \& Mandelstam, J. (1983). Cloning of the Bacillus subtilis lys and spoIIIB genes in phage $\phi 105$. Journal of General Microbiology 129, 22292240.

Kawamura, F., Saito, H. \& Ikeda, Y. (1979). A method for construction of specialized transducing phage $\rho 11$ of Bacillus subtilis. Gene 5, 87-91.

KaWamura, F., SaIto, H., Hirochika, H. \& KobayaSHI, Y. (1980). Cloning of sporulation gene, spoOF, in Bacillus subtilis with $\rho 11$ phage vector. Journal of General and Applied Microbiology 26, 345-355.
Kawamura, F., Shimotsu, H., Saito, H., Hirochika, H. \& Kobayashi, Y. (1981). Cloning of spoO genes with bacteriophage and plasmid vectors in Bacillus subtilis. In Sporulation and Germination, pp. 109-113. Edited by H. S. Levinson, A. L. Sonenshein \& D. J. Tipper. Washington, DC: American Society for Microbiology.

Levi-Meyrueis, C., Fodor, K. \& Schaeffer, P. (1980). Polyethyleneglycol-induced transformation of Bacillus subtilis protoplasts by bacterial chromosomal DNA. Molecular and General Genetics 179, 589-594.

lopez-Diaz, I., Clarke, S. \& Mandelstam, J. (1986). spoIID operon of Bacillus subtilis: cloning and sequencing. Journal of General Microbiology 132, 341-354.

LOVETT, P. S. \& KegGINs, K. M. (1979). Bacillus subtilis as a host for molecular cloning. Methods in Enzymology 68, 342-357.

Maniatis, T., FritsCh, E. F. \& SambrooK, J. (1982). Molecular Cloning: a Laboratory Manual. Cold Spring Harbor: Cold Spring Harbor Laboratory.

NoRRANDER, J., KEMPE, T. \& Messing, J. (1983). Construction of improved M13 vectors using oligodeoxynucleotide-directed mutagenesis. Gene 26, 101-106.

OKamoto, J., Mudd, J. A. \& MARMur, J. (1968). Conversion of Bacillus subtilis DNA to phage DNA following mitomycin $\mathrm{C}$ induction. Journal of Molecular Biology 34, 429-437.

Peterson, A. M. \& Rutberg, L. (1969). Linked transformation of bacterial and prophage markers in Bacillus subtilis 168 lysogenic for bacteriophage $\phi 105$. Journal of Bacteriology 98, 874-877.

Piggot, P. J., Curtis, C. A. M. \& Lencastre, H. DE (1984). Use of integrational plasmid vectors to demonstrate the polycistronic nature of a transcription unit (spoIIA) required for sporulation of Bacillus subtilis. Journal of General Microbiology 130, 2123-2136.

RUTBERG, L. (1969). Mapping of a temperate bacteriophage active on Bacillus subtilis. Journal of Virology 3, 38-44.

Savva, D. \& Mandelstam, J. (1984). Cloning of the Bacillus subtilis spoIIA and spoVA genes in phage $\phi 105 \mathrm{DI}: 1 \mathrm{t}$. Journal of General Microbiology 130, 2137-2145.

SEgALl, J. \& Losick, R. (1977). Cloned Bacillus subtilis DNA containing a gene that is activated early during sporulation. Cell 11, 751-761.

TANAKA, T. (1979), recE4-independent recombination between homologous deoxyribonucleic acid segments of Bacillus subtilis plasmids. Journal of Bacteriology 139, 775-782.

TURner, S. M. \& MANDElstaM, J. (1986). Cloning and sequencing of a gene from Bacillus amyloliquefaciens that complements the sporulation gene spoIID in Bacillus subtilis. Journal of General Microbiology 132, 3025-3035.

Uhlen, M., Flock, J.-I. \& Phillipson, L. (1981). RecE independent deletions of recombinant plasmids in Bacillus subtilis. Plasmid 5, 161-169.

Venema, G. (1979). Bacterial transformation. Advances in Microbial Physiology 19, 245-331.

Yasbin, R. E., Wilson, G. A. \& YounG, F. E. (1973). Transformation and transfection in lysogenic strains of Bacillus subtilis 168. Journal of Bacteriology 113, 540-548. 